\title{
EFEKTIVITAS MODEL PEMBELAJARAN INKUIRI TERBIMBING TERHADAP KETERAMPILAN PROSES SAINS DAN PEMAHAMAN KONSEP FISIKA SISWA MA RIYADHUS SOLIHIN
}

\author{
Sulistiyono \\ STKIP PGRI Lubuklinggau, Lubuklinggau, Indonesia \\ Email. Suliswae85@gmail.com
}

\begin{abstract}
Abstrak
Penelitian ini bertujuan untuk mengetahui efektivitas penggunaan model pembelajaran inkuiri terbimbing dalam meningkatkan keterampilan proses sains dan pemahaman konsep fisika. Jenis penelitian yang dunakan dalam penelitian ini adalah quasi-experiment research menggunakan pretest posttest control group design. Popolasi dalam penelitian ini adalah semua siswa kelas X MA Riyadhus Sholihin teknik pengambilan sampel menggunakan cluster random sampling kelas X MIPA 1 sebagai eksperimen dan kelas X MIPA 3 sebagai kelas kontrol. Keterampilan proses sains diukur dengan menggunakan tes esay untuk keterampilan proses sains intelektual dan observasi untuk mengukur keterampilan proses sains manual. Pemahaman konsep fisika siswa diukur dengan menggunakan tes objekti. Data hasil penelitian dianalisis dengan menggunakan Uji MANOVA dan korelari Pearson. Pemahaman konsep fisika siswa diukur dengan menggunakan soal tes. Berdasarkan hasil penelitian menunjukkan bahwa model pembelajaran inkuiri terbimbing efektif untuk meningkatkan keterampilan proses sains dan pemahaman konsep fisika siswa di kelas X MA Riyadhus Sholihin pada materi Suhu dan kalor.
\end{abstract}

Kata kunci: inkuiri terbimbing, keterampilan proses sains, pemahaman konsep fisika.

\begin{abstract}
This study aims to determine the effectiveness of using guided inquiry learning models in improving science process skills and understanding of physics concepts. The type of research used in this study is a quasi-experimental research using a pretest posttest control group design. The population in this study were all students of class X MA Riyadhus Sholihin. The sampling technique used cluster random sampling was class X MIPA 1 as an experiment and class X MIPA 3 as a control class. Science process skills are measured using essay tests for intellectual science process skills and observations to measure manual science process skills. Students' understanding of physics concepts was measured using an objective test. The research data were analyzed using the MANOVA test and Pearson correlation. Students' understanding of physics concepts was measured using test questions. Based on the results of the research, it shows that the guided inquiry learning model is effective for improving science process skills and understanding the concept of physics of students in class X MA Riyadhus Sholihin on temperature and heat material.
\end{abstract}

Keywords: guided inquiry, science process skills, understanding of physics concepts.

\section{Pendahuluan}

Pendidikan termasuk aspek penting dalam mencerdaskan masyarakat. Pendidikan dianggap dapat mengubah tingkah laku dan berpikir dalam kehidupan bermasyarakat. Berdasarkan Peraturan Kemendikbud Tahun 2013 No 65, visi dari Pendidikan nasional adalah membuat kondisi pembelajaran yang membuat peserta didik berpartisipasi menggali kemampuan dirinya yang mempunyai pribadi yang baik, kepintaran, akhlak mulia, dan tingginya spiritual keagamaan. Peserta didik harus bisa mengggali pengetahuan, sikap, maupun ketrampilan untuk hidup lebih baik pada era globalisasi.

Pemerintah telah berusaha untuk menciptakan pendidikan yang berkualitas di Indonesia, diantaranya adalah memberikan pelatihan-pelatihan untuk meningkatkan kualitas 
guru. Pemerintah juga terus melakukan perbaikan-perbaikan pada kurikulum. Kurikulum yang diterapkan saat ini yaitu Kurikulum 2013. Pemerintah telah merevisi kurikulum dari kurikulum 2013 ke kurikulum 2013 revisi 2016. Kurikulum nasional ini mengarahkan pada kegiatan pembelajaran yang menitikberatkan kepada peserta didik. Harapannya agar peserta didik menjadi bertambah paham dan mengerti mengenai konsep yang telah diajarkan di kelas.

Kemajuan IImu Pengetahuan, Teknologi, dan Seni (IPTEKS) semakin pesat di semua aspek kehidupan. Kemajuan IPTEKS memacu semua negara untuk meningkatkan kompetensi masyarakatnya. Kompetensi-kompetensi yang dikembangkan mengacu pada ide 21st century skills. Pendidikan adalah sebuah sarana penting untuk menyampaikan dan menanamkan kompetensi-kompetensi (pengetahuan). Untuk membangun masyarakat yang berpengetahuan di abad 21, maka ada kompetensi yang dibangun melalui pendidikan, yaitu: (1) keterampilan hidup dan berkarir, (2) keterampilan belajar dan berinovasi (berpikir kritis, berkomunikasi efektif, bekerja kolaboratif dan kreatif), keterampilan atau melek informasi, melek media, dan melek Teknologi Informasi dan Komunikasi (TIK). Kompetensi pengetahuan abad ke 21 dapat diwujudkan dengan empat dasar, yaitu (1) dukungan lingkungan belajar, (2) pengembangan profesi, (3) kurikulum dan proses pembelajaran, (4) standar dan proses assesment (Lubis et al., 2011:6).

Kurikulum sebagai salah satu cara untuk mencapai tujuan pendidikan. Kurikulum yang sedang diterapkan di Indonesia saat ini adalah kurikulum 2013. Kurikulum 2013 mengedepankan pada pengalaman personal melalui observasi, asosiasi, bertanya, menyimpulkan, mengkomunikasikan. Oleh karena itu peran guru sangat penting. Guru memiliki peran sebagai fasilitator, manajer, pembimbing sekaligus teman. Peran guru sebagai manajer dapat dilihat dari aktivitas guru dalam menyiapkan pembelajaran. Peran guru sebagai fasilitator, pembimbing dan sekaligus sebagai teman dapat dilihat dari aktivitas guru dalam melaksanakan proses pembelajaran. Proses pembelajaran diharapkan dapat menumbuhkan kreativitas, inovasi dan keterampilan siswa.

Proses pembelajaran diharapkan memberi lima pokok pengalaman belajar, yaitu : (1) mengamati, (2) menanya, (3) mengumpulkan informasi, (4) mengasosiasi, dan (5) mengkomunikasikan (Kemdikbud, 2013: 8). Hal ini sejalan dengan proses pembelajaran fisika yang tidak hanya fokus pada konten materi saja tetapi juga sebagai upaya memahami berbagai fenomena alam secara sistematis. Proses pembelajaran tersebut diharapkan dapat meningkatkan kemampuan bernalar, kerja ilmiah dan sikap ilmiah siswa. Sikap ilmiah siswa dapat ditumbuhkan melalui rasa ingin tahu siswa menyelidiki fenomena yang ada di alam. Menalar dengan logis dan memecahkannya melalui prosedur yang benar melalui metode ilmiah yang meliputi empat hal pokok yaitu : (1) merumuskan hipotesis, (2) merancang dan 
melaksanakan penyelidikan, (3) mengumpulkan dan menganalisis data, (4) menarik kesimpulan (Sukardjo : 2012:46).

Proses pembelajaran yang mengedepankan pengalaman personal melalui observasi, asosiasi, bertanya, menyimpulkan, mengkomunikasikan memerlukan sebuah pendekatan pembelajaran. Salah satu pendekatan pembelajaran adalah inkuiri. Pendekatan inkuiri merupakan kegiatan pembelajaran yang menekankan pada proses berpikir analitis untuk mencari dan menemukan sendiri jawaban dari masalah yang dihadapi. Melalui pembelajaran dengan pendekatan inkuiri, siswa diharapkan terlibat secara aktif dalam pembelajaran dengan melakukan kegiatan-kegiatan yang berorientasi ilmiah sehingga memberi dampak perolehan pengetahuan dari proses pembelajaran yang tidak hanya sekedar hafalan (Agustin \& Supardi, 2014: 15).

Model pembelajaran dengan pendekatan inkuiri dipilih karena berdasarkan rujukan dari hakikat pembelajaran sains sejak kurikulum pertama disusun. Hal itu dapat terlihat dalam pembelajaran fisika yang tidak lepas dari proses penyelidikan atas sebuah masalah dan menemukan solusi dari masalah yang diberikan (Sulistiyono:2017). Jenis inkuiri yang dipilih adalah inkuiri terbimbing dengan pertimbangan bahwa siswa belum terbiasa dilepas tanpa kontrol guru selama proses pembelajaran. Siswa masih perlu dibimbing ketika menghadapi persoalan atau kehilangan arah dalam proses penyelidikan sehingga sangat diperlukan peran guru untuk mengarahkan siswa melalui pertanyaan-pertanyaan pancingan agar siswa tetap bisa menuju ke arah pembelajaran yang sudah di rancang.

Inkuiri terbimbing dipilih dengan seting siswa bekerja dalam kelompok. Bekerja dalam kelompok diharapkan terjadi debat untuk memecahkan masalah yang dihadapi dan memberi kesempatan komunikasi. Debat memungkinkan terciptanya perbedaan hipotesis dari data dan nilai fakta untuk menguraikan kesimpulan (Demirbag \& Gunel: 2014). Perbedaan hipotesis sebagai awal terciptanya komunikasi sehingga memberi kesempatan kepada semua siswa untuk berusaha menjelaskan argumen dari sebuah hipotesis yang dipaparkan. Penjelasan argumen tersebut diharapkan membimbing siswa untuk meneliti ulang data-data yang telah tersaji pada tabel dan grafik yang ada sebagai dasar untuk menguraikan sebuah kesimpulan. Selain itu Saliman juga menyatakan bahwa pembelajaran inkuiri lebih efektif dalam meningkatkan keterampilan berpikir dan hasil belajar.

Model pembelajaran inkuiri terbimbing dapat memberikan kesempatan kepada peserta didik untuk melakukan kegiatan belajar secara aktif. Cara ini menuntun peserta didik untuk memperoleh pengalaman yang lebih banyak melalui keterlibatan secara aktif, dibandingkan jika mereka hanya membaca suatu materi atau konsep. Model pembelajaran ini tidak hanya menekankan aspek kognitif saja tetapi peserta didik ikut merasakan dan mengalami langsung mengenai apa saja yang dipelajari, sehingga proses pembelajaran menjadi lebih bermakna. 
Keterampilan proses sains merupakan bagian dari kerja ilmiah. Kerja ilmiah tersebut dapat dibelajarkan melalui pembelajaran inkuiri. Menarik kesimpulan penting karena sebagai keputusan akhir dari sebuah masalah yang diselidiki. Melalui kesimpulan yang dibuat, siswa mengerti apakah proses penyelidikan yang dilakukan sudah membantu untuk menemukan solusi. Hal yang lebih penting dari menemukan solusi adalah dapat memberikan pengalaman kepada siswa dalam mengkonstruksi pengetahuannya sendiri. Kenyataan di lapangan menyatakan bahwa guru masih kesulitan mengajarkan konsep fisika dengan metode inkuiri. Hal itu diperkuat dari hasil penelitian (Sulistiyono, 2017) menyatakan bahwa ketercapaian kerja ilmiah masih tergolong rendah, salah satunya keterampilan proses sains. Disisi lain hasil penelitian (Fauzy et al. 2013:8) yang menyatakan bahwa ada empat potret pembelajaran fisika di sekolah yang mumnya terjadi, yaitu: (1) menoton dan cenderung menggunakan metode ceramah, (2) kegiatan praktikum jarang dilakukan, (3) guru jarang menggunakan metode diskusi dalam pembelajaran, (4) keterbatasan waktu guru dalam mempersiapkan pembelajaran. Berdasarkan fakta di atas, maka peneliti ingin meneliti pembelajaran fisika dengan inkuiri terbimbing terhadap keterampilan proses dan pemahaman konsep fisika siswa.

\section{Metode}

Jenis penelitian yang digunakan dalam penelitian ini adalah eksperimen semu (Quasi Experiment Research). Dengan rancangan penelitian ini, pengaruh perlakukan dapat diketahui dengan akurat karena dapat membandingkan dengan keadaan sebelum diberi perlakuan dan tidak memungkinkan untuk mengontrol semua variabel dalam penelitian. Terdapat dua kelompok dalam penelitian ini yaitu kelas eksperimen dan kelas kontrol. Desain yang digunakan dalam penelitian ini adalah pretest - posttest control group design untuk menguji signifikansi pengaruh perlakuan. Dalam rancangan ini, kelas eksperimen diberi perlakuan dengan model pembelajaran inkuiri terbimbing, sedangkan kelas kontrol diberi perlakuan dengan pembelajaran konvensional (Sugiyono: 2012: 79). Selanjutnya hasil pretest dan posttest kedua kelas tersebut dibandingkan, adapun pola rancangan penelitian quasi experiment research yang akan digunakan adalah sebagai berikut.

Tabel 1. Rancangan Penelitian

\begin{tabular}{|l|l|l|l|l|}
\hline No & Kelas & Pretest & Perlakuan & Posttest \\
\hline 1 & Eksperimen & $\mathrm{O}_{1}$ & $\mathrm{X}_{1}$ & $\mathrm{O}_{3}$ \\
\hline 2 & Kontrol & $\mathrm{O}_{2}$ & $\mathrm{X}_{2}$ & $\mathrm{O}_{4}$ \\
\hline
\end{tabular}

Teknik pengumpulan data pada penelitian ini adalah tes dan non tes. Tes digunakan untuk mengukur pemahaman konsep fisika siswa. Non tes digunakan untuk mengukur keterampian proses sains siswa. Pemahaman konsep penelitian ini diukur pada tingkatan ranah kognitif $\mathrm{C} 1, \mathrm{C} 2, \mathrm{C} 3$ dan $\mathrm{C} 4$ menurut BNSP yang meliputi mengingat, memahami, 
mengaplikasikan dan menganalisis. Instrumen yang digunakan berupa soal pretest untuk mengetahui kemampuan awal siswa dan soal posttest untuk mengetahui kemampuan siswa setelah memperoleh perlakuan berupa model pembelajaran inkuiri terbimbing. Instrumen yang digunakan untuk mengetahui KPS terdiri dari lembar observasi kegiatan pembelajaran. Keterampilan proses sains yang diobservasi pada KPS manual meliputi: mengamati, menggunakan alat/bahan, mengajukan pertanyaan, melakukan penyelidikan dan mengkomunikasikan. Instrumen berupa lembar observasi yang diisi oleh observer pada saat kegiatan pembelajaran berlangsung.

Uji normalitas bertujuan untuk mengetahui kenormalan sebaran data dan untuk memenuhi persyaratan pengujian statistik pada uji hipotesis. Uji normalitas dilakukan terhadap data kemampuan menarik kesimpulan dan kemampuan berkomunikasi pada kelas eksperimen dan kelas kontrol. Uji normalitas dalam penelitian ini menggunakan One Sample Kolmogorov Smirnov karena data penelitian merupakan data kuantitatif dengan skala pengukuran interval atau rasio. Sebaran data bersifat normal jika harga probabilitas hitungan (p) > 0,05. Harga probabilitas hitungan ditunjukkan oleh nilai Asymp Sig.

Uji homogenitas dimaksud untuk mengetahui apakah sampel yang diambil secara acak berasal dari populasi yang homogen atau tidak. Uji homogenitas dilakukan terhadap tes baik terhadap pretest posttest kemampuan menarik kesimpulan dan kemampuan berkomunikasi. Menurut Budi (2016 : 175), sampel penelitian dikatakan homogen apabila nilai probabilitas (p) $>0,05$.

Uji hipotesis digunakan untuk membuktikan hipotesis bahwa model pembelajaran inkuiri terbimbing efektif untuk meningkatkan keterampilan proses sains dan pemahaman konsep fisika siswa di kelas X MA RIYADHUS SOLIHIN dengan menggunakan uji Multivariate of Variance (MANOVA).

\section{Hasil dan Pembahasan}

Sajian analisis deskriptif digunakan untuk menyajikan data yang diperoleh berdasarkan hasil pengukuran keterampilan proses siswa dan pemahaman konsep fisika siswa yang dilakukan dengan menggunakan statistika deskriptif software SPSS versi 20. Hasil analisis deskriptif terhadap KPS awal (pretest) dan pemahaman konsep awal (pretest) menunjukkan bahwa antara peserta didik pada kelas kontrol dan kelas eksperimen mempunyai kemampuan awal yang hampir sama dengan selisih nilai rata - rata 0,39 pada KPS awal dan 2,18 pada pemahaman konsep awal. Perbedaan nilai rata-rata juga diuji dengan uji beda yang memiliki nilai signifikansi 0,866 pada KPS dan 0,577 pada pemahaman konsep. Nilai signifikansi lebih besar dari 0,05 maka $\mathrm{H}_{\circ}$ diterima, sehingga dapat disimpulkan bahwa tidak terdapat perbedaan nilai pretest KPS dan pemahaman konsep antara kelas eksperimen dan kelas kontrol. 
Nilai standar deviasi, nilai maksimum dan minimum KPS awal dan pemahaman konsep awal pada kelas eksperimen maupun kelas kontrol terdapat pada Tabel 2. Hasil analisis tersebut menunjukkan bahwa kedua kelas memiliki kemampuan KPS awal dan pemahaman konsep awal yang sama dilihat dari nilai maksimum dan minimum yang hampir sama. Kedua kelas juga memiliki nilai standar deviasi yang menunjukkan bahwa antara kelas eksperimen dan kelas kontrol memiliki variabilitas data yang homogen.

Posttest dilakukan untuk mengetahui kemampuan KPS dan pemahaman konsep pada materi suhu dan kalor setelah mendapatkan perlakuan yaitu model pembelajaran inkuiri terbimbing untuk kelas eksperimen dan kelas kontrol dengan pembelajaran seperti biasa di sekolah. Hasil analisis deskriptif terhadap KPS akhir (posttest) dan pemahaman konsep akhir (posttest) diperoleh nilai rata - rata pada kelas eksperimen lebih tinggi dibandingkan nilai rata - rata kelas kontrol. Hal tersebut menunjukkan bahwa antara kelas eksperimen dan kelas kontrol memiliki KPS dan pemahaman konsep yang berbeda jauh. Selisih nilai rata rata KPS antara kelas eksperimen dan kelas kontrol adalah 18,72, sedangkan selisih nilai rata - rata pemahaman konsep adalah 14,10, sehingga dapat dikatakan bahwa kelas eksperimen memperoleh nilai rata - rata yang lebih tinggi setelah mendapatkan perlakuan inkuiri terbimbing. Perbedaan nilai tersebut dianalisis lebih lanjut dengan menggunakan uji MANOVA untuk menguji hipotesis.

Nilai maksimum dan minimum posttest baik KPS maupun pemahaman konsep antara kelas eksperimen dan kelas kontrol menunjukkan nilai yang berbeda. Hal tersebut menunjukkan bahwa kedua kelas tersebut memiliki kemampuan pemahaman konsep dan KPS yang sangat berbeda. Selain itu, kedua kelas juga memiliki nilai standar deviasi yang menunjukkan bahwa antara kelas eksperimen dan kelas kontrol memiliki variabilitas data yang homogen.

Tabel 2. Nilai KPS (Pretest \& Posttest) dan Pemahaman Konsep (Pretest \& Posttest) Siswa Kelas Kontrol dan Eksperimen

\begin{tabular}{|l|c|c|c|c|c|}
\hline \multirow{2}{*}{ Unit Analisis } & \multirow{2}{*}{ Kelas } & \multicolumn{4}{|c|}{ Jenis } \\
\cline { 3 - 6 } & & Mean & Maksimum & Minimum & STDEV \\
\hline \multirow{2}{*}{ KPS Awal } & Kontrol & 40,26 & 56,67 & 26,67 & 8,00 \\
\cline { 2 - 6 } & Eksperimen & 39,87 & 53,33 & 23,33 & 8,40 \\
\hline \multirow{2}{*}{$\begin{array}{l}\text { Pemahaman } \\
\text { konsep awal }\end{array}$} & Kontrol & 36,28 & 56,67 & 10,00 & 13,74 \\
\cline { 2 - 6 } & Eksperimen & 34,10 & 60,00 & 13,33 & 14,25 \\
\hline \multirow{2}{*}{ KPS Ahir } & Kontrol & 69,49 & 86,67 & 60,00 & 7,28 \\
\cline { 2 - 6 } & Eksperimen & 88,21 & 96,67 & 76,67 & 5,43 \\
\hline \multirow{2}{*}{$\begin{array}{l}\text { Pemahaman } \\
\text { konsep ahir }\end{array}$} & Kontrol & 73,85 & 93,33 & 60,00 & 7,76 \\
\cline { 2 - 6 } & Eksperimen & 87,95 & 96,67 & 76,67 & 6,27 \\
\hline
\end{tabular}

Sebelum melakukan uji hipotesis, terlebih dahulu dilakukan uji normalitas dan homogenitas terhadap nilai pretest dan posttest baik pada KPS maupun pemahaman konsep fisika siswa. Uji normalitas dilakukan untuk mengetahui apakah data yang terkumpul 
berdistribusi normal atau tidak. Uji normalitas dalam penelitian ini menggunakan uji Kolmogorov - Smirnov pada taraf signifikansi 0,05, sedangkan uji homogenitas ini dilakukan untuk mengetahui apakah data nilai pretest dan posttest kelas eksperimen dan kelas kontrol mempunyai varian yang homogen. Uji homogenitas dalam penelitian ini menggunakan uji Levene test. Analisis data untuk mengetahui normalitas data dan homogenitas dilakukan dengan menggunakan software SPSS versi 20. Berdasarkan hasil analisis normalitas, nilai pretest maupun posttest kelas eksperimen dan kontrol pada KPS dan pemahaman konsep menunjukkan bahwa data berdistribusi normal dengan signifikansi lebih dari 0,05 ( $p>0,05)$, sehingga $\mathrm{H}_{\mathrm{O}}$ ditolak.

Tabel 3. HasilUji Normalitas KPS dan Pemahaman Konsep

\begin{tabular}{|c|c|c|c|c|c|}
\hline Unit Analisis & Kelas & Data & Sig. & Taraf Sig. & Keterangan \\
\hline \multirow{4}{*}{ KPS } & \multirow{2}{*}{ Kontrol } & Pretest & 0,200 & \multirow{4}{*}{$P>0,05$} & Berdistribusi Normal \\
\hline & & Posttest & 0,153 & & Berdistribusi Normal \\
\hline & \multirow{2}{*}{ Eksperimen } & Pretest & 0,086 & & Berdistribusi Normal \\
\hline & & Posttest & 0,139 & & Berdistribusi Normal \\
\hline \multirow{4}{*}{$\begin{array}{l}\text { Pemahaman } \\
\text { Konsep }\end{array}$} & & Pretest & 0,200 & \multirow{4}{*}{$P>0,05$} & Berdistribusi Normal \\
\hline & Kontrol & Posttest & 0,191 & & Berdistribusi Normal \\
\hline & \multirow{2}{*}{ Eksperimen } & Pretest & 0,200 & & Berdistribusi Normal \\
\hline & & Posttest & 0,060 & & Berdistribusi Normal \\
\hline
\end{tabular}

Berdasarkan hasil analisis homogenitas, baik pada KPS dan pemahaman konsep dapat diketahui bahwa nilai pretest maupun posttest kelas eksperimen dan kelas kontrol memiliki varian homogen dengan signifikansi lebih dari 0,05 ( $p>0,05)$, sehingga $\mathrm{HO}$ ditolak.

Tabel 4. Hasil Uji Homogenitas KPS dan Pemahaman Konsep

\begin{tabular}{|l|l|l|l|}
\hline Unit Analisis & Data & Sig. & Keterangan \\
\hline \multirow{2}{*}{ KPS } & Pretest & 0,914 & Homogen \\
\cline { 2 - 4 } & Posttest & 0,130 & Homogen \\
\hline $\begin{array}{l}\text { Pemahaman } \\
\text { Konsep }\end{array}$ & Pretest & 0,699 & Homogen \\
\cline { 2 - 4 } & Posttest & 0,518 & Homogen \\
\hline
\end{tabular}

Berdasarkan data yang diperoleh pada penelitian ini, KPS intelektual berupa 10 soal esai dan KPS manual diperoleh berdasarkan hasil observasi terhadap performansi peserta didik pada saat praktikum materi suhu dan kalor. Hasil penelitian menunjukkan bahwa KPS intelektual peserta didik kelas eksperimen an kelas kontrol sebelum pembelajaran berlangsung (pretest) yaitu sama atau tidak berbeda nyata. Setelah kelas eksperimen diberikan pembelajaran dengan model pembelajaran inkuiri terbimbing dan kelas kontrol diberikan pembelajaran konvensional, hasil KPS intelektual kelas kontrol menunjukkan nilai yang lebih rendah dibandingkan kelas eksperimen. Hal tersebut dapat dilihat pada Gambar berikut ini. 


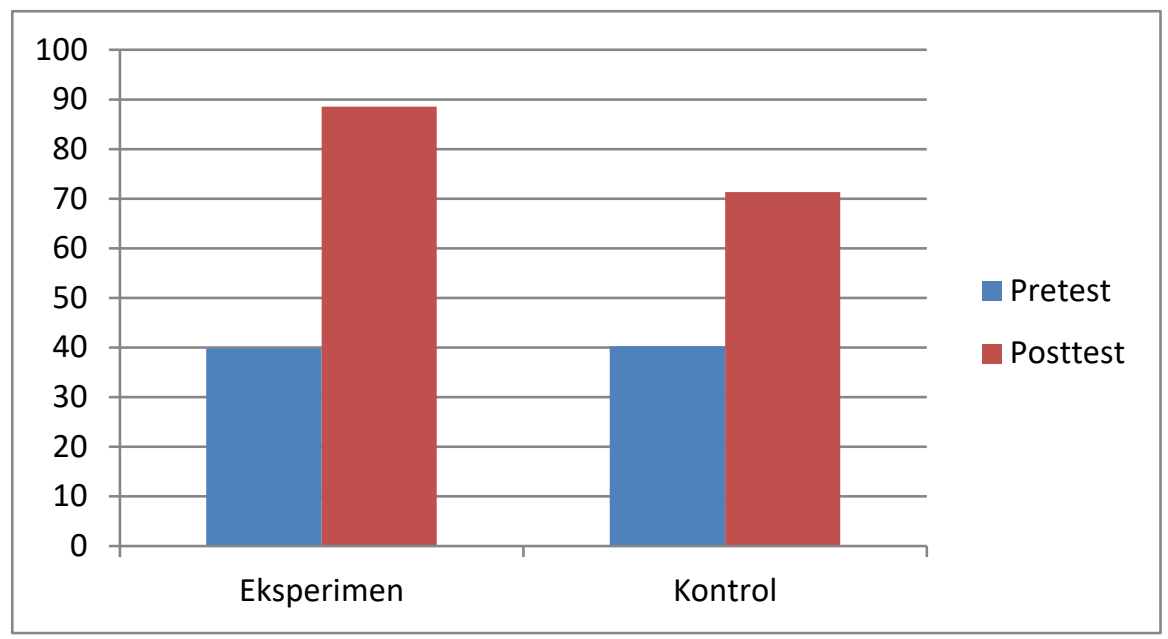

Gambar 1. Nilai KPS Intelektual Kelas Eksperimen dan Kontrol

Nilai pretest KPS intelektual peserta didik kelas eksperimen dan kontrol relatif sama, sedangkan nilai posttest KPS intelektual peserta didik setelah diterapkan model pembelajaran inkuiri terbimbing berbeda. Hal tersebut dibuktikan dengan uji MANOVA pada output Test Between Subjects Effects yang memiliki nilai signifikansi antara model pembelajaran inkuiri terbimbing terhadap KPS peserta didik sebesar 0,000 . Nilai probabilitas lebih kecil dari 0,05, maka kedua nilai berbeda sangat nyata. Dari hasil uji MANOVA Test Between Subjects Effects menunjukkan bahwa model pembelajaran inkuiri terbimbing efektif meningkatkan KPS siswa pada materi suhu dan kalor di kelas $\mathrm{X}$.

Tabel 5. Hasil Uji MANOVA Test Between Subjects Effects

\begin{tabular}{|l|l|r|r|l|}
\hline \multirow{2}{*}{ Source } & Dependet Variabel & $\begin{array}{c}\text { Mean } \\
\text { Square }\end{array}$ & \multicolumn{1}{c|}{ F } & Sig. \\
\hline \multirow{2}{*}{ Coorrected Model } & P Konsep & 2585,940 & 52,059 & .000 \\
\cline { 2 - 5 } & KPS & 4555,138 & 110,287 & .000 \\
\hline \multirow{2}{*}{ Intercept } & P Konsep & 340304,232 & 6850,890 & .000 \\
\cline { 2 - 5 } & KPS & 323267,654 & 7826,849 & .000 \\
\hline & P Konsep & 2585,940 & 52,059 & .000 \\
\cline { 2 - 5 } & KPS & 4555,138 & 110,287 & .000 \\
\hline
\end{tabular}

Berdasarkan hasil analisis uji gain score dapat diketahui bahwa proses pembelajaran dengan model pembelajaran inkuiri terbimbing dapat meningkatkan KPS intelektual siswa dengan kategori tinggi. Pembelajaran dengan model inkuiri terbimbing pada kelas eksperimen dengan langkah sebagai berikut: Identifikasi masalah, Membuat hipotesis, Mengumpulkan data, Menganalisis data dan Mengambil kesimpulan. Pada penelitian ini, siswa mampu melewati tahap-tahap pembelajaran tersebut dalam model pembelajaran inkuiri terbimbing. Peserta didik mampu mengamati, merasakan, berfikir sesuai pengalaman yang dialaminya, mengerjakan tugas yang tertera dalam LKPD (Lembar Kerja Peserta Didik), mampu berdiskusi kelompok dengan baik dan melakukan praktikum pada materi suhu dan kalor (Sulistiyono:2014). Selain itu, siswa mampu menganalisis setiap pembelajaran yang diperoleh melalui pengalaman yang diterima. Hal ini ditunjukkan dengan siswa 
menceritakan pengalaman dalam melakukan kegiatan praktikum. Hal tersebut berarti siswa telah menjalani tahap pengalaman konkrit (concrete experience). Hal ini sejalan dengan pendapat Suciati et al. (2017: 30), yang menyatakan bahwa adanya pengalaman belajar akan menjadikan peserta didik untuk lebih aktif dalam proses pembelajaran baik itu dalam melakukan eksperimen maupun mengerjakan tugas dari guru. Pengalaman konkrit juga dapat mengembangkan fungsi otak pada bagian korteks sensori, sehingga peserta didik selalu aktif bertanya saat pembelajaran berlangsung.

Model pembelajaran inkuiri terbimbing dapat meningkatkan KPS intelektual siswa. Hal ini disebabkan karena inkuiri terbimbing memberikan pemikiran yang lebih luas tentang pokok masalah, mempermudah dalam pengumpulan data hasil pengamatan, peserta didik lebih mudah mencari solusi dalam suatu permasalahan dan melatih kreativitas peserta didik dalam mengungkapkan gagasan tanpa batas namun masih dalam cakupan materi yang dipelajari, sehingga memudahkan dalam mengingat materi.

Pada pertemuan kedua dan ketiga, setiap kelompok sudah terlihat dapat bekerja sama dengan baik dalam melakukan kegiatan pembelajaran dengan menggunakan moodel inkuiri terbimbing. Pada kegiatan di akhir pembelajaran, masing-masing kelompok mempresentasikan hasil diskusi. Peserta didik dari kelompok lain selanjutnya berkesempatan memberikan pertanyaan maupun tanggapan kepada kelompok yang mempresentasikan hasil diskusinya. Dengan adanya tahap reflective observation memudahkan peserta didik dalam menjawab soal yang berhubungan dengan aspek mengamati, menafsirkan, mengklasifikasikan dan merumuskan masalah.

Pada pembelajaran fisika dengan menggunakan model inkuiri terbimbing tahap terakhir membuat kesimpulan. Pada tahap ini siswa dilatih dalam membuat kesimpulan. Pada kegiatan tersebut sebagian besar peserta didik tidak mengalami kesulitan siswa juga tidak mengalami kesulitan dalam membuat kesimpulan berdasarkan rumusan masalah yang telah dibuat sebelumnya dan berdasarkan pengalaman belajar yang mereka alami selama proses pembelajaran. Hal tersebut relevan dengan pernyataan Baharuddin \& Wahyuni (2015: 117) yang menyatakan bahwa pengetahuan akan menjadi lebih bermakna melalui pengalaman. Dengan adanya pengalaman ilmah tersebut maka peserta didik akan mendapatkan pengetahuan keterampilan proses.

Proses pembelajaran dengan menggunakan model pembelajaran inkuiri terbimbing tidak hanya membantu siswa kelas eksperimen dalam meningkatkan KPS yang melibatkan proses berpikir (minds-on) dari berbagai aspek seperti identifikasi masalah, membuat hipotesis, mengumpulkan data, menganalisis data dan mengambil kesimpulan. Penelitian ini juga dapat dilihat dari hasil observasi KPS manual yang dilakukan oleh observer. KPS manual ini melibatkan kemampuan prosedural (hands-on) seperti aspek mengidentifikasi masalah, membuat hipotesis, mengumpulkan data, menganalisis data dan membuat kesimpulan. Hasil 
observasi KPS manual siswa dilakukan sebanyak tiga kali pertemuan, yakni data awal (pretest) diperoleh pada pertemuan pertama, sedangkan data akhir (posttest) diperoleh pada pertemuan ketiga.

Tabel 6. Hasil Observasi KPS Manual Siswa

\begin{tabular}{|c|l|c|c|c|c|c|c|}
\hline \multirow{2}{*}{ No } & \multirow{2}{*}{ Kelas } & $\begin{array}{c}\text { Pretes } \\
\mathrm{t}\end{array}$ & $\begin{array}{c}\text { Posttes } \\
\mathrm{t}\end{array}$ & Min & Maks & Min & Maks \\
\hline 1 & Kontrol & 60,26 & 68,72 & 46,67 & 66,67 & $\begin{array}{c}60,0 \\
0\end{array}$ & 80,00 \\
\hline 2 & Eksperimen & 82,57 & 96,41 & 66,67 & 93,33 & $\begin{array}{c}93,3 \\
3\end{array}$ & 100 \\
\hline
\end{tabular}

Berdasarkan tabel diatas nilai rata-rata KPS manual kelas eksperimen lebih tinggi dibandingkan kelas kontrol han ini menunjukkan bahwa model pembelajaran inkuiri terbimbing memberikan pengaruh atau efektif terhadap KPS siswa dalam melakukan kegiatan ilmiah yang di bimbing oleh guru sehingga kegiatan ilmiah dapat dilaksanakan sesuai prosedur yang ada untuk mencapai tujuan pembelajaran, sedangkan pada kelas kontrol yang menggunakan model pembelajaran koonvensional, siswa belum dapat melakukan prosedur sesuai dengan tujuan pembelajaran karena siswa tidak terlatih dalam mencapai aspek KPS. Oleh karena KPS manual pada penelitian ini bukan tes performansi, melainkan sebuah observasi mengenai performansi siswa dalam kegiatan praktikum materi suhu dan kalor, maka model pembelajaran inkuiri terbimbing dapat memberikan pembelajaran yang efektif meningkatkan KPS manual siswa.

Pembelajaran dengan menggunakan model pembelajaran inkuiri terbimbing dapat menciptakan pembelajaran yang lebih inovatif, dengan melibatkan pengalaman sebagai sumber pengetahuan sehingga siswa dapat mengembangkan KPS menjadi lebih aktif, kreatif, terampil dalam berpikir dan terampil dalam memperoleh pengetahuan. Menurut Ridyah \& Siti (2016: 125), KPS sangat penting untuk diterapkan peserta didik agar lebih memudahkan dalam mengaplikasikan suatu konsep, prinsip dan teori sains yang melibatkan aktifitas fisik, mental dan sosial. Model pembelajaran inkuiri terbimbing selain efektif meningkatkan KPS manual maupun KPS intelektual, model pembelajaran ini juga efektif meningkatkan pemahaman konsep peserta didik karena peserta didik melakukan sendiri kegiatan pembelajaran untuk menemukan konsep atau fakta.

Hasil penelitian menunjukkan bahwa pemahaman konsep peserta didik kelas eksperimen dan kelas kontrol sebelum pembelajaran berlangsung (pretest) yaitu sama atau tidak berbeda nyata. Setelah kelas eksperimen diberikan pembelajaran dengan model pembelajaran inkuiri terbimbing dan kelas kontrol diberikan pembelajaran konvensional, hasil pemahaman konsep kelas eksperimen lebih tinggi dibandingkan kelas kontrol. Nilai pretest pemahaman konsep siswa kelas eksperimen dan kontrol relatif sama, sedangkan nilai 
posttest pemahaman konsep peserta didik setelah diterapkan model pembelajaran inkuiri terbimbing berbeda. Hal tersebut dibuktikan dengan uji MANOVA pada output Test Between Subjects Effects yang memiliki nilai signifikansi antara model pembelajaran inkuiri terbimbing terhadap KPS siswa sebesar 0,000. Nilai signifikansi lebih kecil dari 0,05, maka kedua nilai berbeda sangat nyata. Dari hasil uji MANOVA Test Between Subjects Effects menunjukkan bahwa model pembelajaran inkuiri terbimbing efektif meningkatkan pemahaman konsep siswa pada materi suhu dan kalor di kelas X MA.

Pemahaman konsep antara kelas eksperimen dan kelas kontrol berbeda karena siswa belajar melalui pengalaman sebagai sumber belajar atau pembelajaran bukan hanya materi yang bersumber dari guru dan selama proses pembelajaran siswa dibantu dengan praktikum yang dapat mempermudah peserta didik dalam memahami materi pelajaran. Berdasarkan hasil analisis uji gain score dapat diketahui bahwa proses pembelajaran dengan model pembelajaran inkuiri terbimbing dapat meningkatkan pemahaman konsep siswa dengan kategori tinggi.

Tabel 7. Hasil Nilai $N$ - Gain Score Pemahaman Konsep Peserta Didik

\begin{tabular}{|c|c|c|c|c|c|}
\hline \multirow{2}{*}{ Kelas } & \multicolumn{2}{|c|}{ Nilai rata-rata } & \multirow{2}{*}{ Peningkatan } & \multirow{2}{*}{$\begin{array}{l}\text { Nilai N-Gain } \\
\text { Score }\end{array}$} & \multirow{2}{*}{ Kategori } \\
\hline & Pretest & Posttest & & & \\
\hline Kontrol & 42,81 & 74,89 & 37,57 & 0,61 & Sedang \\
\hline Eksperimen & 39,42 & 88,61 & 53,85 & 0,88 & Tinggi \\
\hline
\end{tabular}

Dilihat dari segi teoritis, model pembelajaran inkuiri terbimbing berdasarkan teori Kolb lebih berpusat pada pengalaman dalam proses pembelajaran. Model pembelajaran inkuiri terbimbing sejalan dengan teori belajar konstruktivisme, peserta didik memperoleh pengetahuan dari pengalaman yang mereka pelajari. Association for Experiential Eduaction (AEE) mendefinisikan pembelajaran melalui pengalaman adalah proses dimana siswa membangun pengetahuan, keterampilan dan nilai dari pengalaman langsung (Purnami dan Rohayati, 2013: 101). Pembelajaran tersebut lebih menekankan pada proses belajar dengan menggunakan pengalaman peserta didik dalam kehidupan sehari - hari, sehingga pembelajaran menjadi lebih kondusif dan menyenangkan.

Model pembelajaran inkuiri terbimbing berbeda dengan model pembelajaran yang biasa digunakan oleh guru karena pembelajaran tersebut membuat kesan menyenangkan, peserta didik semangat untuk mengikuti pelajaran dan dapat bekerja sama dengan baik dalam kelompok diskusi. Pembelajaran dengan model pembelajaran inkuiri terbimbing menuntut peserta didik berperan aktif selama proses pembelajaran dan peserta didik dilatih dengan menggunakan pengalaman nyata sebagai awal dari pembelajaran yang kemudian dipresentasikan. Peserta didik juga saling berinteraksi dalam diskusi kelompok untuk mencari tahu pengalaman lain dari teman atau ide pokok maupun konsep guna mencapai hasil belajar yang lebih optimal. 


\section{Simpulan dan Saran}

Berdasarkan hasil analisis data dan pembahasan yang telah di paparkan di atas, maka diperoleh kesimpulan sebagai berikut: Model pembelajaran inkuiri terbimbing efektif untuk meningkatkan keterampilan proses sains siswa di kelas X MA Riyadhus Sholihin pada materi Suhu dan kalor. Model pembelajaran inkuiri terbimbing efektif untuk meningkatkan pemahaman konsep siswa di kelas X MA Riyadhus Sholihin pada materi Suhu dan kalor.

Berdasarkan hasil penelitian yang diperoleh maka dapat diajukan saran sebagai berikut (1) Penelitian penggunaan model pembelajaran inkuiri terbimbing untuk meningkatkan KPS dan pemahaman konsep pada materi yang lain perlu dilakukan. (2) Peneliti menyarankan dalam penggunaan model pembelajaran inkuiri terbimbing dapat didiskusikan peserta didik di luar jam pelajaran apabila pembelajaran di sekolah kekurangan waktu.

\section{Daftar Pustaka}

Agustin, R, Risa \& Supardi, Z.A.I. (2014). Penerapan Model Pembelajaran Inkuiri Terbimbing untuk Melatihkan Kemampuan Keterampilan Berpikir Kritis Siswa Kelas XI SMAN 1 Kalianget. Jurnal Inovasi Pendidikan Fisika, 3, 14-19.

Baharuddin dan Wahyuni, N. (2015). Teori belajar dan pembelajaran. Yogyakarta: Ar-ruzz Media.

Budi. (2016). Pengaruh model pembelajaran sains teknologi masyrakat terhadap pemahaman konsep biologi dan keterampilan berpikir kreatif siswa SMA. e-Journal Program Pascasarjana Universitas Pendidikan Ganecha.

Demirbag, M. \& Gunel, M. (2014). Integrating Argument-Based Science Inquiry with Modal Representations: Impact on Science Achievement, Argumentation, and Writing Skills. Educational Science 14 (1): 386391.

Fauzy et al. (2013) Pembelajaran Fisika Berbasis Inkuiri, Perspektif Teori Belajar. Jurnal Pendidikan Widya Dharma, 23, 77-91

Kemendikbud. 2013.Kerangka Dasar Kurikulum 2013.Kementerian Pendidikandan Kebudayaan Direktorat Jenderal Pendidikan Dasar . Jakarta.

Lubis, M,. Muthmainnah., Nurdin., Chaeruman, U. A \& Saeffudin. (2011). Kompetensi Guru. Jakarta : Teknologi Pendidikan UNJ.

Permendikbud No. 65 Tahun 2013Tentang Standar Proses Pendidikan Dasar danMenengah.

Purnami, Rahayu, S., dan Rohayati. (2013). Implementasi metode experiential learning dalam pengembangan softskills mahasiswa yang menunjang integrasi teknonlogi, manajemen dan bisnis. ISSN 1412-565: 98-104.

Ridyah, S. W. dan Siti, S. (2016). Pembelajaran IPA terpadu tipe connected model experiential learning untuk meningkatkan keterampilan proses sains siswa SMP. EDUSAINS, 8 (2): 122-127. 
Suciati, Chrisnia, O., dan Luthfiana, N. (2017). Hubungan antara keterampilan laboratorium dengan kemampuan kognitif siswa pada penerapan kolbs experiential learning model (KELM) di kelas XI. Seminar Nasional Pendidikan Sains II UKSW.

Sugiyono. (2012). Metode penelitian kuantitatif, kualitatif dan $R \& D$. Bandung: Alfabeta.

Sukardjo : 2012 Optimalisasi Pendidikan Karakter dalam Pendidkan Sains Masa Depan. Yogyakarta : makalah disampaikan pada seminar nasional pendidikan sains pada tanggal 3 November 2012 di UNY.

Sulistiyono, S., \& Dewiyanti, F. (2014). Penerapan Model Prediction, Observation, Explanation (POE) untuk Meningkatkan Hasil Belajar Fisika Siswa Kelas X1 SMA Negeri 8 Lubuklinggau Tahun Pelajaran 2012/2013. Jurnal Perspektif Pendidikan, 8(1), 16-21.

Sulistiyono, M., \& Kuswanto, H. (2017). Pengembangan Panduan Praktikum Fisika Berbasis Inkuiri Untuk Mengembangkan Keterampilan Berpikir Siswa SMA. Jurnal Inovasi Dan Pembelajaran Fisika, 4(1), 89-98.

Sulistiyono, S. (2017). Pengembangan lembar kerja siswa dengan pendekatan kerja laboratorium untuk meningkatkan keterampilan proses fisika. SPEJ (Science and Physic Education Journal), 1(1), 59-64.

Sulistiyono, S., Mundilarto, M., \& Kuswanto, H. (2019). Keefektifan pembelajaran fisika dengan kerja laboratorium ditinjau dari ketercapaian pemahaman konsep, sikap disiplin, dan tanggung jawab siswa sma. Compton: Jurnal Ilmiah Pendidikan Fisika, 6(1), 35-43. 